AUTHOR:

Cornelia Smith

AFFILIATION:

Tshwane University of Technology

CORRESPONDENCE TO:

Cornelia Smith

EMAIL ADDRESS:

Smithcga@tut.ac.za

DATES:

Published: 12 Nov 2018

HOW TO CITE THIS ARTICLE:

Smith, C.G.A, 2018. Learner-

centeredness: A multiple intelligence approach to reveal individual learner

preferences for curriculum content in Foundation Phase. KOERS - Bulletin

for Christian Scholarship, 83(1).

Available at: https://doi.org/10.19108/ KOERS.83.1.2218

COPYRIGHT:

(c) 2018. The Author(s)

Published under the Creative Commons Attribution License.

\section{Learner-centredness: A multiple intelligence approach to reveal individual learner preferences for curriculum content in Foundation Phase}

\begin{abstract}
Gardner's concept of multiple intelligences can directly link with the subjects or the curriculum taught in school. The focus in this paper is on Foundation Phase learners and their personal favourite subjects. In allowing learners to choose what they find the most interesting, the most popular subject is identified and new perspectives are provided on which areas should receive attention. The method involved is a quantitative approach incorporating statistics obtained through a Likert scale. 105 participants were involved and interesting views surfaced. Literacy (in terms of reading and writing) is no longer at the top of the list of most popular subjects, and this is a concern for teachers who aim at teaching learners to read and write - Art was found to be the most popular subject. Fusing Art and other forms of intelligences can be employed as a strategy to teach literacy and popularise it.
\end{abstract}

Keywords: Intelligence type, Foundation Phase, Learner, subject, learner-centredness and motivation

\section{Opsomming}

Gardner se onderskeid tussen multi-intelligensie tipes kan direk in verband gebring word met die vakke wat op skool onderrig word. Die fokus in hierdie navorsingstuk is op die Grondslagfase en die leerders se persoonlike gunstelingvakke. Nuwe lig op populêre vakke word gewerp deur leerlinge die geleentheid te bied om hulle persoonlike voorkeure uit te oefen. Hierdie metode stel navorsers in staat om vas te stel wat om te doen om die probleem van swak geletterdheid aan te spreek. 'n Kwantitatiewe metode is gevolg om leerderkeuses te identifseer en resultate is in persentasies weergegee. 105 deelnemers was betrokke en interessante perspektiewe het aan die lig gekom. Geletterdheid is nie die gewildste veld nie en Kuns is een van die Grondslagfaseleerders se voorkeure. Indien kuns dan ingespan kan word in ander vakke as deel van integrasie kan dit moontlik die leer in daardie vakke bevorder.

Kernbegrippe: Intelligensietipe, Gronds/agfase, Leerder, vak, leerdergesentreerdheid en motivering.

\section{INTRODUCTION}

The realm of pedagogy can be regarded as a neglected field as far as research studies are concerned, especially in the light of probing possible quality education (Schweisfurth, 2015:259). Learner-centred education (LCE) has been a global concern especially when endeavouring to initiate improvements to teaching and learning and it has even been called the panacea, but it is characterised as fraught with many problems embracing a lack of definition and implementation challenges (Schweisfurth, 2015:259). Cristina (2015:28) refers to the challenges in the Romanian educational society as the elephant in the room, which cannot be ignored. She promotes an efficient education system that can address educational challenges. De Klerk-Luttig (2015:1) identifies the inequality in 
the South African education system as a serious problem in education. Strauss and Daniels (2013:291) describe the education system as a time bomb. These examples underscore the need to investigate ways to improve the education system as education is in dire straits even in overseas countries.

The researcher argues for a perspective of teaching and learning including the learners' voices indicating learner preferences for learning content in the Foundation Phase. Providing the learner with choices can cast light on which learning area is most enjoyed and which subject does not really feature as part of the curriculum. Providing new insight into learner choices can also provide more information so that remedial teaching can take place and subjects can all be accorded their rightful place as part of the curriculum with the focus on holistic development. Possible intervention strategies can be decided on. In order to view the areas of learning which embrace the subject content taught at school, Gardner's theory of multiple intelligences will be incorporated as it links well with the subjects taught in the Foundation Phase. LCE and motivation will also be addressed as part of the investigation to understand learner choices.

\section{LITERATURE REVIEW}

\subsection{A theoretical framework}

\subsubsection{Gardner's multiple intelligence theory (MI)}

Gardner (1983:279) is of the opinion that humans manage to interpret and understand their surroundings through logical and mathematical analysis, spatial representations, musical involvement, the use of bodily movement and communicating and understanding natural surroundings and especially taking an interest in nature. Humans differ in their intellectual profiles. Gardner emphasises that all intelligence types should enjoy equal measure of attention, since they all form building blocks that should be scaffolded onto for later learning (Wessels, 2010:6). Learners are unique and teachers need to cater for individual differences and needs. A possible way to improve the understanding of learners and their choices is for teachers to identify individual needs and choices when planning lessons (Lindeque \& Vandeyar, 2010:120).

MI theory propounds that human beings can possess a complex set of special abilities that extend the parameters of what is measured and what is known as an IQ (Intelligence Quotient). Intelligence is described as more than a range of abilities that aid the learner in solving problems. This view is crucial as it focuses attention on the fact that learners' own unique strengths and weaknesses can be handled to the benefit of the learner when deciding on instruction in the classroom. Essential to the application of MI, is provision of various ways or entry points to show what they have learnt (Parker, 2016:3).

Gardner's MI theory as suggested in 1993 on intelligence types embraces the following eight areas:

- $\quad$ Linguistic intelligence (LI) referring to the ability to process words and use the language;

- Logical mathematical intelligence (LMI) referring to the ability to deal with numbers, mathematical and logical patterns;

- $\quad$ Musical intelligence (MI) referring to the ability to process and understand rhythm and sounds;

- $\quad$ Spatial intelligence (SI) referring to the ability to understand and interpret shapes, arrays and direction;

- Bodily-kinaesthetic intelligence (BKI) referring to the ability to process sensations movement and co-ordination;

- Interpersonal intelligence (Inl) referring to the ability to communicate social- 
ly;

- Intrapersonal intelligence (Irl) referring to self-efficacy and self-knowledge;

- $\quad$ Naturalistic intelligence (NI) referring to the ability to deal with categories and to build models (Yeganeh \& Dezfouli, 2015:12).

Manamara (2015:4) adds the following types of intelligence as proposed by the relevant critics. They are:

- General intelligence as proposed by Schmidt and Hunter in 2000;

- Emotional intelligence as proposed by Mayer and Salovey in1997;

- $\quad$ Collective intelligence as proposed by Levy in 1997;

- Creative intelligence as proposed by Nussbaum in 2013;

- $\quad$ Cultural intelligence as proposed by Sternberg in 1985;

- $\quad$ Social intelligence as proposed by Sternberg in 1985;

- $\quad$ Analytic intelligence as proposed by Sternberg in 1985;

- $\quad$ Practical intelligence as proposed by Sternberg in 1985;

- $\quad$ Competitive intelligence as proposed by Knip, Dishman and Fleisher;

- $\quad$ Digital intelligence as proposed by Adams in 2004.

Macnamara (2015:4) observes that many of the above-mentioned intelligence types are not supported by empirical evidence but recognises the value of identifying all these intelligence types as in the past only linguistic and mathematical intelligences were highlighted and emotional intelligence was neglected. It can be contended that Gardner's interpersonal and intrapersonal intelligence embrace emotional intelligence as emotional intelligence entails managing relationships and reactions to communicative aspects, yet recognising that holistic intelligence as identified by Macnamara (2015:4), embraces all these aspects identified. Macnamara (2015:4) emphasises that intelligence should in fact incorporate cognition as well as emotions. For the purposes of this investigation Gardner's eight categories as mentioned above can serve as the focus intelligence types as they incorporate all these aspects mentioned.

Ekinci (2014:627-628) links multiple intelligences with academic scores and maintains that learners with higher multiple intelligence scores are more likely to demonstrate good reading comprehension scores. She asserts that MI scores can be regarded as predictors of academic success. Referring to the impact of multiple intelligence scores it is even more vital to test popularity of intelligence types (subjects) to identify the area that should be promoted to achieve a holistic approach to the promotion of intelligence types, since a higher multiple intelligence score influences language learning to mention one reason.

Gardner's intelligence types can also be linked with different subjects. Subjects taught in the Foundation Phase, viz. Maths, Literacy and Life skills which span human movement, knowledge of music, drama, art and even outside play and cultural space are all part of the prescribed syllabus CAPS (Lemmer, Meier \& van Wyk, 2012:116-118).

Jacobs (2010:35) explains "curriculum" in terms of a race that is run, once the desirable knowledge is mastered. Curriculum is also explained in terms of the following:

- $\quad$ Subject: the subjects taught as part of the course;

- $\quad$ Content: The prescribed outcomes or content included for the subject;

- $\quad$ Planned activities: Curriculum extends the definition of content as activities to entrench learning can also form part of the curriculum;

- In-school experiences: Planned as well as unplanned experiences are included.

Integrated learning also happens via play in the Foundation Phase as a means to simplify the content and to connect with the learner at his/her level. Weisberg, Kittredge, Hitsch- 
Pasek, Golinkoff and Klahr (2015:9) acknowledge the value of free play as teaching strategy of the curriculum content but propose that guided play can be more functional in assisting Foundation Phase learners to achieve academic outcomes in all areas of the school curriculum.

\subsubsection{Learner-centred education (LCE)}

Altay (2013:140) is of the opinion that learner-centred instruction embodies the application of diverse methods that place the learner at the centre of education. The shift also involves gaining knowledge from students instead of the teacher just providing all the knowledge. The transfer of knowledge through direct instruction also takes a backseat to active learning through co-operation and collaboration. Students develop self-relying capabilities and social and problem-solving skills.

Schweisfurth (2015:259-260) maintains that LCE should not be regarded as an absolute, but should rather be viewed as a continuum ranging from a less to a more learner-centred practice. Fundamental principles at the heart of an LCE approach include respect for the human rights of learners, and a focus on strengthening their unique learning experiences and capabilities as valued in the respective societies. It is viable to embrace teaching as central to promote quality education and fostering equity among learners. The term "learner" is involved because of the rights foundation of this vision. Rights of necessity trump evidence on learning effectiveness. LCE should be understood as situated within broad cultural norms of a community as well as individual contexts, based on interactions between learners and teachers. Interactions between teachers and learners are not the sole shapers of the climate and practice of teaching and learning as there are also other factors which shape their contours.

Hallinger and Lu (2013:596) underscore the importance of teachers to allow students the opportunity to select their course of study as part of enhancing knowledge and skills in certain domains. Thus, the opportunity to connect course content to personal interest and goals represents a potential source of motivation among learners. This assertion is also supported as the need among mature learners for scaffolding new learning on past experience is salient. Even though Foundation Phase learners cannot decide on their own content they can state their preferences for certain subjects.

Killen (2013:93-94) asserts that learner-centredness can be linked with the choice of a teaching approach by the teacher. The teacher should aim at using a variety of teaching strategies in order to reach all learners in the classroom. Variety of teaching strategies used help learners to link the content with the outcomes. Killen is of the opinion that the teaching strategy can be linked with the content chosen. The researcher is of the opinion that an investigation into learning choices can also influence the teacher's teaching strategies as the choice for content will reveal which subjects or types of intelligences should receive attention and it will also cast light on which teaching strategies should be used to promote the area of neglect.

\subsubsection{Motivation}

A salient factor that resonates through all learning areas is the influence of motivation. Lessons need to be engaging and motivating illuminating salient aspects of the respective subjects. Learner motivation and cognitive development are central to the curriculum implementation. It stems not only from what learners are experiencing in the classroom, but also from cultural expectations and respect for, education and teachers. Motivation can be achieved through pedagogical practice and is embedded in the pedagogical nexus (Schweisfurth, 2015:259-260).

Mozgalina (2015:120) asserts that motivation can be linked inextricably with self- 
determination. Three types of motivation are identified viz.:

- $\quad$ Amotivation which is the least determined level of motivation, which is demonstrated when learners find no persuasion to engage in tasks as they see no challenge to become competent nor do they identify the value thereof;

- Intrinsic motivation, which entails the most self-determined motivation, which is demonstrated by autonomous decisions;

- $\quad$ Extrinsic motivation, which is demonstrated when the instrumental outcomes are linked with the purpose of the action. Extrinsic motivation is further sub-divided into three groups, viz.; external regulation, introjected regulation, and identified regulation.

Intrinsic motivation has been deemed the most influential force as it encourages greater engagement, creativity and motivation especially in people's relationships and activities. Intrinsic motivation linked with task engagement is recognised in the educational research literature as a crucial condition for any kind of learning to take place.

Fellowes and Oakley (2013:159) link literacy learning in Foundation Phase with motivation. They assert that children are most likely motivated if they experience success when the content is pitched at the appropriate level. They highlight the fact that learner choices should be taken into account when providing learning and reading material. They warn against challenges that can cause frustration for the learners and continue to state that if learners are interested in the learning material, they will most likely perform better. Reading and writing must be taught having a clear purpose in mind. These above-mentioned aspects pertaining to motivation are also in support of an approach to take cognisance of learner input and learner votes for preference of study material even subjects or intelligence types involved. Fellowes and Oakley (2013:568) further identify the following aspects to be part of motivating learners to learn viz. using texts for communicative purposes, providing apt feedback and guidance, the classroom climate and even the teacher's attitude can impact the learners' level of motivation.

Wessels (2010:143) links positive feedback with motivation and refers to the learning of a language by means of positive remarks to the young learner as a measure to entrench vocabulary as young as the stage that the child starts cooing. Mwamwenda (2014:186) identifies certain aspects that impact on learner motivation as part of social learning. They are:

- $\quad$ Attention: the learner has to pay adequate attention to succeed;

- Memory: Observations must be made carefully in order for learners to remember what they learnt;

- Motor skills: Any skills required to master must be entrenched and explained by examples to motivate the learner;

- $\quad$ Reinforcement: Learning occurs as response to reinforcement;

- Identification: If the learner identifies with the same sex it will motivate him in acquiring the appropriate skills;

- The status of a model: The behaviour of a more caring person is more likely to be modelled and interest plays a crucial role in modelling and consequently motivation.

It can thus be gathered from the above-mentioned aspects that a learner will be motivated if he is participating in an interesting subject that is taught in an entertaining way. 


\section{RESEARCH METHODOLOGY}

\subsection{Design}

A quantitative approach was followed. According to Bless, Higson-Smith and Sithole (2013:17) a quantitative approach displays a more rigid structure containing big samples to enable objective responses to the data gathered. It seeks to generalise findings and tests a theory. It also provides statistics and numbers. A quantitative approach seemed to be viable in order to answer the research question of this study viz.: which intelligence type as presented as a subject in Foundation Phase is the most popular. The idea is to cast light on learner preferences to make improvements to teaching strategies to enhance learning. It can also reveal whether the main subjects are afforded their rightful position.

\subsection{Participants}

35 Grade 1 Foundation Phase students, 35 Grade 2 and 35 Grade 3 Foundation Phase students attending a Gauteng township school were invited to participate in the study. The school that participated is a rural township school with a dynamic leader, proposing cooperation with the universities to benefit growth and development in his school.

\subsection{Ethics}

Bless et al. (2013:28-29) assert that ethics can be linked directly with character and morals. The study must be guided by principles that protect the learners especially if they are impressionable. One of the most basic principles involved is that the participants must not be harmed and should be protected. They should also be allowed to stop participating whenever they feel like it. These basic ethical principles were taken into account.

Permission was sought from the Department of Basic Education (DoBE) and from the school in question as the idea was to raise an awareness of improved learning and teaching in the Foundation Phase. The school in question remains anonymous.

\subsection{Instrument}

In order to approach the Foundation Phase learners in a user-friendly way a questionnaire was designed using faces ranging from most friendly to least friendly to elicit a response with regard to the preference for learner content. To make it user-friendly it was connected with the concept of play.

Davin, Orr, Marais and Meier (2012:249) provide useful tips for making the learning environment of the emergent learner more exciting including play and exploration and daily reading in the classroom as essential ingredients of fostering a love for learning.

Naudé and Meier (2014:54-56) identify five types of play when playing with numbers viz.:

- $\quad$ exploratory play also known as heuristic play which involves the exploration of possibilities of objects such as using a whisk in a mixing bowl;

- construction play when using blocks to build a tower;

- creative play when they play with the shoes of the learners to build a new pattern;

- $\quad$ physical and locomotor play such as counting the skips or hops they execute;

- fantasy play when they realize twenty five learners cannot fit into a corner as they are too many;

- $\quad$ playing shopping when selling and buying and determining the cost of things and word play as mathematic vocabulary is learnt and used.

The element of play is thus present in many activities done in class without the learners realising that are actually learning new knowledge. 
Compare the following instrument used in this study to obtain quantitative data:

\begin{tabular}{|c|c|c|c|c|c|c|}
\hline MYCHOICES & 5 & 4 & 3 & 2 & & CHOICE \\
\hline play with crayons and paint & 20 & $\stackrel{0}{0}$ & $\begin{array}{ll}0 & 0 \\
\end{array}$ & 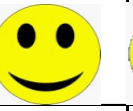 & & \\
\hline Play-storytelling and puppets & $\because$ & 2 & $\begin{array}{ll}0 & 0 \\
\end{array}$ & $\begin{array}{lll}0 & 0 \\
& \end{array}$ & $\underbrace{0}$ & \\
\hline Play outside & $\because$ & & 00 & 0 & $\underbrace{0}$ & \\
\hline Play with numbers & $\because 6$ & 2 & 00 & 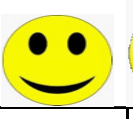 & & \\
\hline Play -Reading books & $\because$ & & 00 & $\underbrace{0}$ & & \\
\hline Play-Music & $\because$ & & 00 & $\underbrace{1}$ & & \\
\hline Play by myself & $\because$ & & 00 & 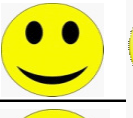 & & \\
\hline Play with friends & $\because$ & 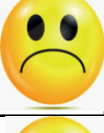 & 00 & $\underbrace{0}$ & $\pi$ & \\
\hline & $\because$ & $\stackrel{\circ}{0}$ & 00 & $\left(\begin{array}{lll}0 & 0 \\
& 0\end{array}\right.$ & & \\
\hline
\end{tabular}

Figure 1

Educators were asked to assist the learners and explain what to do without intimidating them with regard to their personal choices on a scale from 1-5, 1 being the most enjoyed and 5 the least enjoyed. The instrument was photocopied and each of the participants received a questionnaire of his/her own to complete. They had to evaluate on a scale from the subject most enjoyed to the least enjoyed. The instrument used in this study was a structured questionnaire, with close questions in order to elicit statistics to form part of the discussion and the quantitative approach. A questionnaire using the Likert scale was designed and tailor-made for the purpose of testing learner response to a variety of activities. Designing a questionnaire poses a number of concerns as the participants were Foundation Phase learners. In order to make the answering fun and to tie in with the theme of play, faces were used and the use of faces in designing questionnaires was investigated. Reynolds-Keefer, Johnson, Dickenson and McFadden (2004:1) maintain that the use of pictures in Likert scales does not seem to make a difference in response and teachers may use pictorial and textbased scales interchangeably for yes or no as substitutes. Smiley faces were then selected to indicate preferences from least to most popular. Learners were also required to indicate the activity most enjoyed. The teaching strategies stories, drama and puppets, drawing and painting, playing outside, playing on the computer and playing with numbers all form part of the questionnaire. All eight types of intelligences (Matthaei, 2010:1) were included and represented by a type of play.

Reynolds-Keefer and Johnson (2011:1) warn against exaggerated faces in research questionnaires and the researcher therefore tried to keep to simple faces as far as possible (compare the faces used in addendum A). Haddad, King, Osmond and Heidari (2012:1) 
suggest that when keeping the respondents motivated and interested the cartoon method of using faces can be used fruitfully. They also assert that conveying facial expression through cartoon illustrations can be a suitable method with guidance and sustained interest as long as respondents are monitored and guided throughout the process.

Nativida Saracho (1997:82) stresses the importance of studying the individual needs of children in order for them to perform optimally. She maintains that: "The content of an early childhood curriculum can be identified and its appropriateness justified in many ways. Teachers must include in the content of early childhood education more than a set of skills that enable children to function adequately and meet the demands of schooling. The content of early childhood education requires diversity in the early childhood curriculum in order that all children learn based on their needs and interests".

Compare the following grid designed in order to clarify these suggested types of intelligences as suggested by Gardner (1983:279) linked with the teaching strategies and subjects:

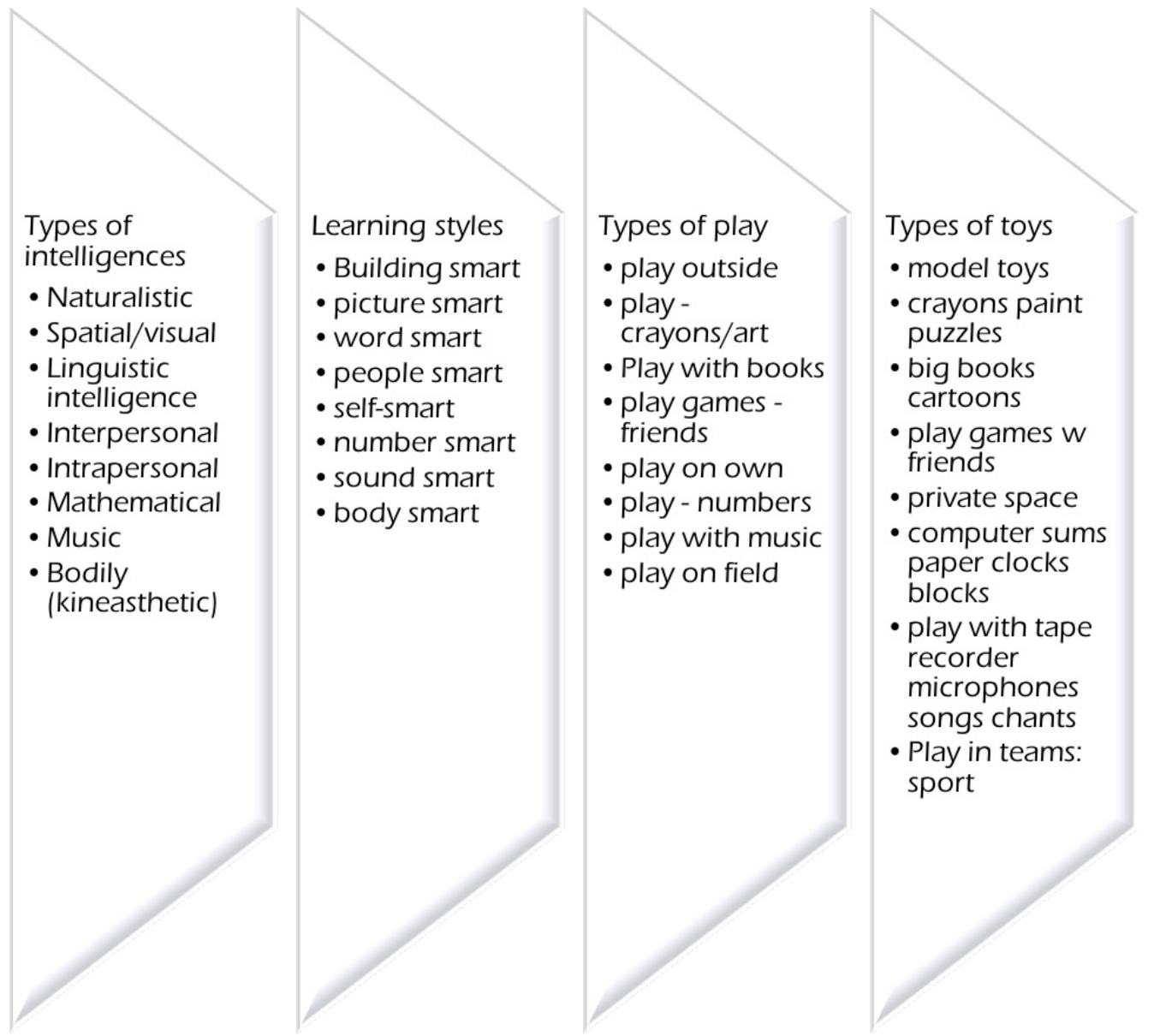

Figure 2

When studying figure 2. It is evident that all the various types of intelligences are included and these types of intelligences were then also included in the questionnaire used to vote for the learners' choices from the least to most enjoyed. 


\section{FINDINGS AND DISCUSSION}

Compare the following:

Figure 3

\begin{tabular}{|l|l|l|l|}
\hline Summary & $\begin{array}{l}\text { Grade } \\
3\end{array}$ & $\begin{array}{l}\text { Grade } \\
2\end{array}$ & $\begin{array}{l}\text { Grade } \\
1\end{array}$ \\
\hline Playing with pencils and paint-drawing and painting (Art) & $91 \%$ & $100 \%$ & $100 \%$ \\
\hline Playing :dramatising stories- puppets (Language: drama) & $65 \%$ & $91 \%$ & $74 \%$ \\
\hline Playing outside (Life skills) & $74 \%$ & $44 \%$ & $50 \%$ \\
\hline Playing with numbers (Mathematics) & $91 \%$ & $63 \%$ & $89 \%$ \\
\hline Playing with reading books (Language) & $87 \%$ & $91 \%$ & $97 \%$ \\
\hline Playing with music (Life skills) & $77 \%$ & $76 \%$ & $66 \%$ \\
\hline Playing by myself (Life skills) & $49 \%$ & $34 \%$ & $60 \%$ \\
\hline Playing with friends (Life skills) & $76 \%$ & $94 \%$ & $94 \%$ \\
\hline
\end{tabular}

\subsection{Discussion}

When studying figure 3, a summary of the votes of the participants, it can be inferred from the statistics accumulated that drawing and painting stay at the top of the list when it comes to the most enjoyable content. $91 \%$ of Grade 3 learners and 100\% of Grade 1 and 2 learners prefer this subject as their favourite subject. Teachers should therefore gear their teaching towards employing artistic tasks to enrich and make other types of learning (playing) more fun. Employing arts as part of all forms of play might add more popularity to certain unpopular activities. In the light of the recent focus on literacy and creating a literate society, it is alarming to note that preferences for the language activities take a backseat to Life skills. Duncam (2015:297) focuses on the value of art in education and asserts that even copying from popular media and being enable learners to live out their preoccupations, fears, and aspirations via fantasy. Learners can facilitate their own development when they draw upon cultural forms about things they are passionate about producing loving pictures filtered through their personal transgressive and sometimes resistant culture. Drawing also enables learners to produce highly imaginative parodies and help them to work through social contradictions of cultural forms (Duncam, 2015:299).

The focus has recently been on improving literacy levels of learners (DoBe, 2014) and the learner preference for the Arts rather than activities that deal with language development is therefore alarming. Languages need to compete with many other learning areas. As a provincial measure to address the poor performance in literacy and mathematics levels among primary school township learners in Gauteng, the Department of Education (GDE) proposed the Gauteng Primary Schools Literacy and Mathematics Strategy (GPLMS) 20102014 (DoE, 2014).

Literacy skills are deemed as extremely important human resources (Seligman, 2012:15). Campbell (2015:13) emphasises the value of teaching literacy skills to Foundation Phase learners making use of play-based activities that include dramatic play and shared reading moving the emphasis to phonics instruction. Literacy incorporates many forms of communication such as the spoken (phonics) and the written word as well as images and researchers attach the notion of cultural context to the aspects of reading and writing skills in an endeavour to come up with a comprehensive definition of literacy (Seligman, 2012:53).

Literacy is no longer viewed as a set of isolated practices but is regarded as a social 
phenomenon (Mishra Tarc, 2015:123). Mishra Tarc (2015:119) focuses attention on the crucial role that the mother plays in the language development of the infant. The mother's communication is instrumental in supporting the child to acquire language. She refers to Klein's tenets on language learning and contends that the mother sets the scene for the enactment of the infant's mental capacity. The child's sense of the self is pivotal in the development of the mental capacity to look for words outside the self to communicate his perceptions of the world around him/her. It thus involves semiotic and signifying skills and a sound knowledge of symbolic contexts. She maintains that literacy is actually an emotional construct (Mishra Tarc, 2015:122).

Campbell (2015:20) emphasises that there is no single recipe for acquiring literacy. She observes the influences of both socio-cultural and contextual factors the learner has to face as aspects affecting literacy development. She proposes a literacy programme that exceeds the parameters of a single commercial phonics programme. Wildová and Kropáčková (2015:680) propose activities such as the incorporation of drama, theatre and fairy tales as a method to enhance language learning. They promote visual perception and stimuli as incentives to expose learners to opportunities that can trigger the stimulation of the imagination. They also identify the value of motivation when learners are involved in activities that stimulate their imagination that can lead to eager reception of subject content.

Literacy development in the Foundation Phase also involves multiple languages as the Foundation Phase learners in South Africa belong to diverse cultures and speak many languages in class (Lemmer et al., 2012:48). It remains intriguing to me that learners did not opt for languages as their favourite choice and language teachers should take note of this phenomenon in order to make their language teaching more enticing.

The popularity of reading has been seen to show a definite decrease from $97 \%$ in Grade 1 , $91 \%$ in Grade 2 and $87 \%$ in Grade 3. Reading seems to become less popular as soon as the amount of work starts increasing and learners have to be involved with academic reading. Maybe the fun part of reading should receive attention in order to attract the unwilling developing readers. Much must be done to expose them to stimulating reading material.

Puppet shows as a means of storytelling seemed to be most popular with Grade 1.74\% of the participants voted for it to be their favourite activity. In Grade 2 the popularity of puppet shows and puppet playing increased to $91 \%$ but in Grade 3 it is as if the learners start becoming more realistic and they no longer enjoy it as their favourite activity.

Outside play becomes much more popular among the learners as soon as the academic work increases. $74 \%$ of the Grade 3 learners participating in this project voted for outside play as a favourite activity. It shows the importance of sport and participation in athletics. Sport should not be neglected as the learners feel a great need for physical activities when growing older.

The most comforting news is that Maths as subject is much more enjoyed by the older learners (Grade 3: 91\%), as playing with numbers (Mathematics) is most important when learners consider tertiary learning. The statistics show that the Grade 1 learners enjoy Maths more than the Grade 2 learners, but fortunately in Grade 3 they start enjoying it again. Further research on the popularity of Maths among Foundation Phase learners as per grade can yield more information and it can be suggested as a topic of research for the future.

Then popularity of music seems to grow from Grade 1, 66\%, Grade 2, 76\% to Grade 3, 77\%. Music as a life skills subject should receive more attention and for this specific group it might be mentioned that the participating school does not have a piano. Adding music to their songs might enliven the entire experience. Music and music development should not be neglected as part of Life skills as a subject. 
The topic of having a friend to play with is crucial and many a parent has approached the educators on this topic. It is also very clear that all grades did not wish to be playing by themselves but prefer friends. These learners showed a need for socialising even though they are so young. Interesting is that Grade 1 learners were less concerned to play by themselves (49\%) than Grade 2 (34\%) and Grade 3 (60\%) learners. It seems that in Grade 3 they really wish to have friends of their own and to be accepted by a peer group. A possible reason might be that they were used to play by themselves when still at home. In the higher Grades when they start to realise the importance of having friends, it can cause many a learner to feel sad and lonely. Educators must also see to it that learners are socialising and should assist the ones who are battling to find a friend. Playing with a friend can provide endless opportunities for learners to grow and develop socially. They learn what is acceptable and what not. They learn what it is to be loyal and supportive and what to do if rejected. Peer pressure is an important factor in developing and learning as learners will start competing when they start achieving good or less impressive results for tasks when assessed. Coulson (2015) focuses on aspects which can cause children to be desirable as friends. Parents should support their children to interact with friends to solidify their relationships. The children who are the most desirable as friends are often those who perform well at school and whose parents discuss issues and trends with their children, assisting them to find mutually agreeable answers to problems. The role of the teacher to intervene can never be underestimated, since even your colour or race can expose the learner to exclusion by the in-group.

It seems the older these learners become the less they want to play on their own. As for having friends the Grade 3 learners showed a vote of 74\%, the Grade 2 learners 96\% and the Grade 1 learners 96\%. It should be noted that the findings cannot be generalised but should be seen as part of the township environment though certain aspects may be the same for more privileged schools. Damm (2018) asserts that peer pressure does not need to be only a negative influence since even though older children can become more aware of fitting in or not, positive friends can become a positive influence in the developing child's life. Social development and interacting with positive peers are a crucial part of learners' holistic development.

\subsection{Recommendations}

- In order to support a higher level of literacy, teachers should focus on popularising languages and activities that can interest the learners;

- $\quad$ Teachers should use artistic techniques engaging learners by fusing arts and language skills as it can then enhance language learning;

- Teachers should also keep abreast of new developments so that they can modernise their teaching strategies;

- Individual needs should not be neglected as it is part of learner-centred teaching;

- A serious effort should be made to help learners adapt socially so they can make friends as it forms part of their security and social adaptation;

- Music should be accommodated and introduced as an important aspect of Life skills.

\section{CONCLUSION}

Gathering information on the popularity of the subjects as part of learning reveals useful information that can affect the way teachers approach the learners. Teachers should avail themselves to put in an effort to promote teaching of languages. Playing outside is maybe a way of developing that is not really seen as learning but forms an integral part of learner development. Even though academic development is essential, the learners should also be allowed to be children, children who should be allowed to learn incidentally and not only by being drilled towards academic achievement. Incorporating arts as part of teaching 
Foundation Phase learners seems to be a strategy that motivates the young learners and teachers can make full use of this strategy even in an integrated way to promote all subjects. In view of the inequalities still evident in the educational sphere, it is especially important to focus on multiple intelligences, since holistic development of learners need to be a primary focus in a dynamic education system. Provision of the needed areas for development such as the provision of sport fields at schools needs attention, since schools are still without these facilities taken into consideration the participants' ambience in this study. Holistic development incorporating all intelligence types should be a focal point in education, since even physical development can be linked with the development of literacy skills. Exploring outside play remains an area for further research. 


\section{REFERENCES}

ALTAY, B. 2014. User-centred design through learner-centred instruction. Teaching in Higher Education, 19(2): 138-155. https://doi.org/10.1080/13562517.2013.827646

BLESS, C., HIGSON-SMITH, C. \& SITHOLE, S.L. 2013. Fundamentals of social research methods. An African perspective. Cape Town: JUTA \& Company.

CAMPBELL, S. 2015. Feeling the pressure: early childhood educators' reported views about learning and teaching phonics in Australian prior-to school settings. Australian journal of language literacy, 38(1)12-26.

CRISTINA, T. 2015. The elephant in the room or updating the teaching profession. Procedia social and behavioural sciences, 203:28-34. https://doi.org/10.1016/j.sbspro.2015.08.255

COULSON, J. 2015. Peer pressure at school. Retrieved from: kidspot.com: https://www.kidspot.com. au/school/secondary/peer-pressure/peer-pressure-at-school/news-story/4fafcfe5bbc8c458c698df $4 \mathrm{bfc} 18 \mathrm{~d} 484$

DAMM, A. 2018. Negative effects of peer pressure in high schools. Education. Retrieved from: https:// education.media/negative-effects-of-peer-pressure-in-high-school.

DAVIN, R., ORR, J.P., MARAIS, P. \& MEIER, C. 2012. Managing the learning environment in early childhood development centres. In Meier, C \& Marais, P. 2012. Eds. Education management in early childhood. Hatfield: Van Schaik.

DEPARTMENT OF EDUCATION (DoE). 2014. Gauteng Primary Schools Literacy Strategy. 2010-2014. Pretoria: Government Printers.

DE KLERK-LUTTIG, J. 2015. Ruk só swak onderrig reg. Netwerk 24. 6 Januarie 2015. Available from: http://netwerk24.com/stemme/[Acessed:15/8/2015].

DUNCUM, P. 2015. A journey toward an art education for wired youth. Studies in Art Education: A Journal of Issues and Research, 56(4): 295-306. https://doi.org/10.1080/00393541.2015.11518972

EKINCI, B. 2014. The relationships among Sternberg's triarchic abilities, Gardner's multiple intelligences and academic achievement. Social behaviour and personality, 42(4):625-614. https:// doi.org/10.2224/sbp.2014.42.4.625

FELLOWES, J. AND OAKLEY, G. 2013. Language literacy and early childhood education. Australia: Oxford University Press.

HADDAD, S., KING, S., OSMOND P. \& HEIDARI, S. 2012. Questionnaire Design to Determine Children's Thermal Sensation, Preference and Acceptability in the Classroom.

HALLINGER, P. \& LU, J. 2013. Learner centred higher education in East Asia: assessing the effects on student engagement. International Journal of Educational Management, 27(6):594-610. https://doi. org/10.1108/ijem-06-2012-0072

GARDNER, H. 1983. Frames of mind: Multiple intelligences. http://www.businessballs.com/ howardgardnermultipleintelligences.htm [Accessed 6/8/2015].

JACOBS, M. 2010. Curriculum design. In: Jacobs, M., Vakalisa, N \& Gawe, N. Teaching-learning dynamics. A participative approach for OBE. Sandton: Heineman Publishers.

KILLEN, R. 2010. Teaching strategies for quality teaching and learning. Cape Town: Formeset Print.

LEMMER, E.M., MEIER, C. \& VAN WYK, J.N. 2012. Multicultural education. Hatfield: Van Schaik Publishers.

LINDEQUE, B. \& VANDEYAR, S. 2010. Context analysis and diversity. In: Jacobs, M., Vakalisa, N \& Gawe, N. Teaching-learning dynamics. A participative approach for OBE. Sandton: Heineman Publishers.

MOZGALINA, A. 2015. More or less choice? The influence of choice on task motivation and task engagement. System, 49:120-132. https://doi.org/10.1016/j.system.2015.01.004

MACNAMARA, J. 2015. Multiple intelligences and minds as attributes to reconfigure PR. A critical analysis. Public relations review, 42(2):1-9. https://doi.org/10.1016/j.pubrev.2015.03.002

MATTHAEI, S. 2010. Early Childhood - Learning Styles. Examiner.com Sept 4. Retrieved from www. examiner.com . [Accessed 12/8/2015].

MISHRA TARC, A. 2015. Literacy of the other: the inner life of literacy. Journal of childhood education, 15(1):119-140. https://doi.org/10.1177/1468798413512849

MWAMWENDA, T.S. 2014. Educational psychology. An African perspective. Sandton: Heineman. 
NATIVIDAD SARACHO, O. 1997. Teachers' and Students' Cognitive Styles in Early Childhood Education. London: Bergin \& Garvey.

NAUDE, M \& MEIER, C.eds. (2014). Teaching Foundation Phase Mathematics. A guide for South African students and teachers. Hatfield: van Schaik Publishers.

PARKER, J.L. 2016. Academic Success for the 21st Century Learner: Intrapersonal Intelligence and Resilience. Walden University Scholar Works Walden Dissertations and Doctoral Studies Collection. Walden University. Retrieved from: https://scholarworks.waldenu.edu/cgi/viewcontent. cgi? article $=3180 \&$ context $=$ dissertations

REYNOLDS-KEEFER, L. \& JOHNSON, R. 2011. Is a picture worth a thousand words? Creating effective questionnaires with pictures. Practical assessment research and evaluation, 16(8) May.

REYNOLDS-KEEFER, L., JOHNSON, R., DICKENSON, T. \& MCFADDEN, L. 2009. Validity issues in the use of pictorial Likert scales. SLEID. 28ndJan. Retrieved from http://www.plea2012.pe/pdfs/T02-201201280033.pdf .

SCHWEISFURTH, M. 2015. Learner-centred pedagogy: Towards a post-2015 agenda for teaching and learning International Journal of Educational Development, 40 (2015) 259-266. https://doi. org/10.1016/j.ijedudev.2014.10.011

SELIGMAN, J. 2012. Academic literacy for education students. Cape Town: Oxford University press.

STEINBERG, S. (2011). The benefits of video games. ABC News Dec, 26.

STRAUSS, E \& DANIELS, D. 2013. "Dis 'n tydbom ... die skip gaan sink": Emosionele welsyn van Hoërskoolopvoeders in die Helderbergarea van die Wes-Kaap. Tydskrif vir Geesteswetenskappe, 53(3):391-403.

WEISBERG, D.S., KITTREDGE, A.K., HITSCH-PASEK, K., GOLINKOFF, R.M. \& KLAHR, D. 2015. Making play work for education. Kappan magazine, May: 8-13. https://doi.org/10.1177/0031721715583955

WESSELS, M. 2010. Practical guide to participating language learning. Cape Town: Oxford University Press.

WILDOVÁ, R. \& KROPÁČKOVÁ, J. 2015. Early childhood pre-reading literacy development. Procedia social and behavioural sciences, 191:878-883. https://doi.org/10.1016/j.sbspro.2015.04.418

YEGANEH, M. T. \& DEZFOULI, F. B. 2015. The reflection of multiple intelligences (MI) in Iranian English textbooks, teacher' perceptions. Procedia social and behavioural sciences, 192:11-14. https://doi. org/10.1016/j.sbspro.2015.06.002 